which the scientific accuracy of the present day is no real substitute. We want both kinds of illustration; at least a few figures of the old kind to cheer the pages and make them less dull, and to take away the impression that we are dealing with nothing but dried specimens in a museum collection and that the subject is a drab one. Eutheatus erythropygos (Brandt, 1841) is a good example because it is on de Saussure's first plate. Attems gives us a neat little figure (after Carl) of the gonopod, and very useful it is ; but how much more satisfactory it would have been if we could have had de Saussure's delightful drawing of the whole animal reproduced as well. When no figure of the gonopods is available, it is still more to be deplored that no such illustration as that given by de Saussure is included by Attems. An instance of this is provided by Rhysodesmus zapotecus (Sauss.); de Saussure admirably depicts the whole animal.

Sometimes the treatment adopted by Attems is difficult to understand. Take Platyrhacus (Tirodesmus) mexicanus (Lucas); although Attems gives no description, this species is fully described and segments figured by de Saussure. Of the species $P(T)$ bilineatus (Lucas) which de Saussure regards as near $P(T)$ mexicanus, Attems gives a full description with one figure (side-view of gonopod).

When all is said, however, and we come to the end of a series of minor criticisms, we feel that Count Attems has done systematists a great service. More power to his pen!

\section{S. Graham Brade-Birks.}

\title{
GEOLOGY OF INDIA
}

\section{Geology of India}

By D. N. Wadia. Second edition. Pp. $x x+460+$ 20 plates. (London: Macmillan and Co., Ltd., 1939.) 24s. net.

7 HIS book, which from its first appearance 1 has been the standard text-book of Indian students, has now been brought up to date by the addition of recent advances in Indian geology. The new geological map is an added attraction.

The revision has not, however, been sufficiently far-reaching and thorough. As a result, a novice to the subject of Indian geology will occasionally be puzzled by finding both the old and the modern view stated without due explanation.

The Salt-Range is regarded (p. 104 and Fig. 8) as a block-faulted structure, but later in the book we are told that over-thrust faulting is a marked structural feature.

On pp. 146 and 147 , it is noted that the Upper Gondwanas of the Madras coast and probably the Rajmahal beds also must now be regarded as Lower Cretaceous and not as Jurassic. These recent conclusions-the work of Dr. Spath and Prof. Sahni-should have caused a more extensive revision of the whole subject, including alterations in the tables on pp. 51 and 130 .

In the table of the Siwalik stages on p. 271, the views of Dr. Pilgrim as to age are given. But in a later table on p. 280 we find an entirely different view of the ages put forward by Dr. de Terra. An explanatory note was here called for.

Before writing his account of the Bagh Beds and the "Cenomanian Transgression" (p. 206), Mr. Wadia would have done well to have studied the views of Dr. Spath on the subject (Pal. Ind., New Ser. 15, Part 5, 64).
The account of the Samana section and the Hangu Shale fauna is too brief in view of its importance (see p. 246).

Perhaps the most disappointing chapters are those dealing with the Indian pre-Cambrian. There is no basis for the separation of the Himalayan pre-Cambrian into Archæan and Algonkian, as is attempted on pp. 81 and 99, and, as the age of the supposed Burmese pre-Cambrian is even more doubtful, it was not correct to place the Mergui series in the Archæan (p. 54).

Considering the great advance made in the study of the Peninsular pre-Cambrian by the Indian and Mysore Geological Surveys of recent years, the account is meagre and not free from intermixture of old and new views (for example, age of Bundelkhand gneiss on pp. 62, 63 and 73). The modern correlation of these rocks should have been given, and the views of M. S. Krishnan (Twenty-second Indian Science Congress, 1935), which admirably express the general opinions of the staff of the Indian Geological Survey, might have been studied.

In short, the entire rewriting of these chapters, and of that dealing with the Upper Gondwanas, would have improved the book. Nevertheless there is much valuable new material, especially regarding the Salt-Range, North-West India, and Kashmir. The structure of the Himalaya-the results of the work of West, Auden and Wadia himself-is excellently summarized in Chapter xxv. Those portions dealing with marine fossiliferous rocks and with economics are also of a high standard, and, in spite of such defects as those noted above, Mr. Wadia is to be congratulated on his new edition.

G. DE P. COTTER. 